\title{
Sinorhizobium fredii USDA257, a Cultivar-Specific Soybean Symbiont, Carries Two Copies of y4yA and y4yB, Two Open Reading Frames That Are Located in a Region That Encodes the Type III Protein Secretion System
}

\author{
Guoqiao Jiang ${ }^{1}$ and Hari B. Krishnan ${ }^{1,2}$ \\ ${ }^{1}$ Department of Agronomy and ${ }^{2}$ Plant Genetics Research Unit, USDA-ARS, University of Missouri, Columbia \\ 65211, U.S.A. \\ Accepted 12 May 2000.
}

\begin{abstract}
Sinorhizobium fredii USDA257 forms nitrogen-fixing nodules on primitive soybean (Glycine max) cultivar Peking but fails to nodulate the improved cultivar McCall. Cultivar specificity is governed by a plasmid-borne locus, nolXBTUV. By DNA sequence analysis, we have identified two open reading frames, $\mathrm{y} 4 \mathrm{yA}$ and $\mathrm{y} 4 \mathrm{yB}$, immediately downstream of nolX. Northern (RNA) blot analysis indicated that the expression of both $\mathrm{y} 4 \mathrm{yA}$ and $\mathrm{y} 4 \mathrm{yB}$ is inducible by isoflavonoids, and an intact copy of $n o l X$ is required. Two copies each of $\mathrm{y} 4 \mathrm{yA}$ and $\mathrm{y} 4 \mathrm{yB}$ are present in $S$. fredii USDA257, one on the sym plasmid (y4yAsp and y4yBsp), and the other on the chromosome (y4yAc and $\mathrm{y} 4 \mathrm{yBc})$. The cultivar-nonspecific strain USDA191 lacks y4yAc and y4yBc. Introduction of $y 4 y A c$ plus $y 4 y B c$ from USDA257 into USDA191 did not influence the ability of the latter strain to nodulate McCall soybean plants. Unlike nolX, the inactivation of y4yAsp and y4yBsp of USDA257 did not extend the host range of this strain. A double mutant, in which both the plasmid and chromosomal copies of $\mathrm{y} 4 \mathrm{yA}$ and $y 4 y B$ were mutated, had no observable effect on symbiotic ability of USDA257. The y4yAsp and y4yBsp mutants did not influence flavonoid-dependent extracellular protein production. Rhizobium sp. strain NGR234 and $S$. saheli USDA4893 both contain sequences similar to $S$. fredii USDA257 y4yAsp and y4yBsp; however, Bradyrhizobium spp., the traditional soybean symbionts, lack these genes.
\end{abstract}

Corresponding author: Hari B. Krishnan, Plant Genetics Research Unit, USDA-ARS, University of Missouri, Columbia 65211 U.S.A.

Telephone: 1-573-882-8151; Fax: 1-573-884-7850

E-mail: KrishnanH@missouri.edu

Nucleotide and/or amino acid sequence data can be found at the GenBank data base as accession nos. AF229440 and AF229441.

This article is in the public domain and not copyrightable. It may be freely reprinted with customary crediting of the source. The American Phytopathological Society, 2000.
Two genera of rhizobia, Sinorhizobium and Bradyrhizobium, form nitrogen-fixing nodules on soybean (Glycine max (L.) Merr.) roots. Research in our laboratory is focused on the Sinorhizobium fredii-soybean symbiosis. S. fredii USDA257 forms nitrogen-fixing nodules on primitive soybean cultivars such as Peking, but fails to nodulate agronomically improved North American cultivars (Keyser et al. 1982; Heron and Pueppke 1984). A different strain of $S$. fredii (USDA191) forms nodules and fixes nitrogen with both primitive and advanced soybean cultivars (Heron and Pueppke 1984). By means of random Tn5 mutagenesis, several mutants of USDA257 were obtained that were capable of forming nodules on advanced soybean cultivars (Heron et al. 1989). Two such mutants, 257DH4 and 257DH5, have been examined in some detail (Krishnan and Pueppke 1991a; Meinhardt et al. 1993; Kovács et al. 1995; Bellato et al. 1996 1997). 257DH5 contains the transposon in a chromosomal region named nolC. Inactivation of nolC enables 257DH5 to form Fix ${ }^{-}$nodules on McCall (Krishnan and Pueppke 1992). In contrast, mutant 257DH4 forms Fix ${ }^{+}$nodules on McCall and the transposon is located in an 8.0-kb EcoRI fragment located on the symbiosis (sym) plasmid (Heron et al. 1989). DNA sequence analysis of this region has identified several open reading frames (ORFs; nolXWBTUV) and this region has been designated as the hostspecificity locus (Meinhardt et al. 1993).

Insertional mutations within nolB, nolT, nolU, nolV, nolW, and nolX all enabled $S$. fredii USDA257 to form nitrogenfixing nodules on McCall soybean. The results of transcriptional analyses indicate that the genes in the host-specificity locus are transcribed from three promoters (Kovács et al. 1995). The promoters of nolW and nolBTUV are divergently oriented and initiate transcription at sites that are 14 bp apart. Compounds (daidzein and genistein) that regulate the expression of nodABC (Krishnan and Pueppke 1991b) are the most powerful inducers of nolX and nolBTU (Meinhardt et al. 1993; $\mathrm{Gu}$ et al. 1997). Unlike the nodABC genes, the soybean cultivar-specificity genes are not preceded by a conventional nod box (Meinhardt et al. 1993). 
Flavonoids from soybean roots stimulate $S$. fredii USDA257 to secrete several proteins into extracellular medium (Krishnan and Pueppke 1993). The extracellular proteins have been designated as signal-responsive (SR) proteins and their secretion is dependent on a functional regulatory gene, nodD1 (Krishnan et al. 1995). In addition, interruption of the cultivar-specificity locus, nolXWBTUV, also prevents extracellular accumulation of the SR proteins. Recently, we have shown that some of the proteins encoded by the cultivarspecificity locus are extracellular. For example, NolX is an extracellular protein that is exported without $\mathrm{N}$-terminal processing, indicating that type III protein secretion machinery is involved in its transport (Pueppke et al. 1999).

A cluster of genes that encode components of a bacterial type III secretion system (TTSS) has been identified in Rhizobium sp. strain NGR234 (Freiberg et al. 1997; Viprey et al. 1998), a broad-host-range symbiont of numerous legumes (Pueppke and Broughton 1999). The TTSS cluster of NGR234 contains 27 ORFs and includes the soybean cultivarspecificity locus nolXWBTUV (Viprey et al. 1998). Earlier, we reported the nucleotide sequence of a 5,596-bp DNA fragment that encompasses the soybean cultivar-specificity locus (Meinhardt et al. 1993; Kovács et al. 1995). Some of genes encoded in this region have significant sequence similarity with components of type III protein secretion systems of gram-negative pathogens of plants and animals.

To identify all the components of the type III protein secretion system and to locate the boundaries of the cultivarspecificity locus of $S$. fredii USDA257, we initiated sequenc- ing of DNA regions downstream of nolX (Fig. 1). By sequence analysis of 2,000 bp beyond nolX, we have identified two ORFs, one beginning 185 bp downstream of nolX followed immediately by the second ORF. Both ORFs were of the same polarity as nolX. The first ORF is $429 \mathrm{bp}$ in length and the deduced protein has a molecular mass of 15,602 Da. The potential initiation codon for the next ORF overlaps with the previous ORF termination codon. The second ORF is $1,350 \mathrm{bp}$ in length and the deduced 450 amino acid sequences contribute to a protein of $49,175 \mathrm{Da}$. A computer-assisted search of protein data bases indicated a striking similarity between the newly identified ORFs from $S$. fredii and y4yA and y4yB from Rhizobium sp. strain NGR234. Based on this extensive identity, the ORF immediately downstream of nolX was designated as y4yB and the second ORF as y4yA (Fig. 1).

Southern blot analysis with EcoRI-digested genomic DNAs from $S$. fredii USDA257, USDA191, and Rhizobium sp. strain NGR234, a broad-host-range strain related to $S$. fredii (Perret et al. 1994) and its sym-plasmid cured derivative, $A N U 265$, revealed strong hybridizing signals when probed with a $1.4-\mathrm{kb}$ EcoRI/PstI fragment that contains most of y4yB and y4yA (Fig. 2). S. fredii USDA191 contained a single 8.0-kb EcoRI hybridizing band, while $S$. fredii USDA257 and Rhizobium sp. strain NGR234 revealed two hybridizing bands (Fig. 2). The sizes of hybridizing bands in $S$. fredii USDA257 are approximately 8.0 and $4.0 \mathrm{~kb}$, while similar fragments in Rhizobium sp. strain NGR234 are 8.0 and $3.2 \mathrm{~kb}$ (Fig. 2). DNA from the plasmid-cured derivative of NGR234 hybridized only to the $3.2-\mathrm{kb}$ fragment, indicating that this fragment was located on
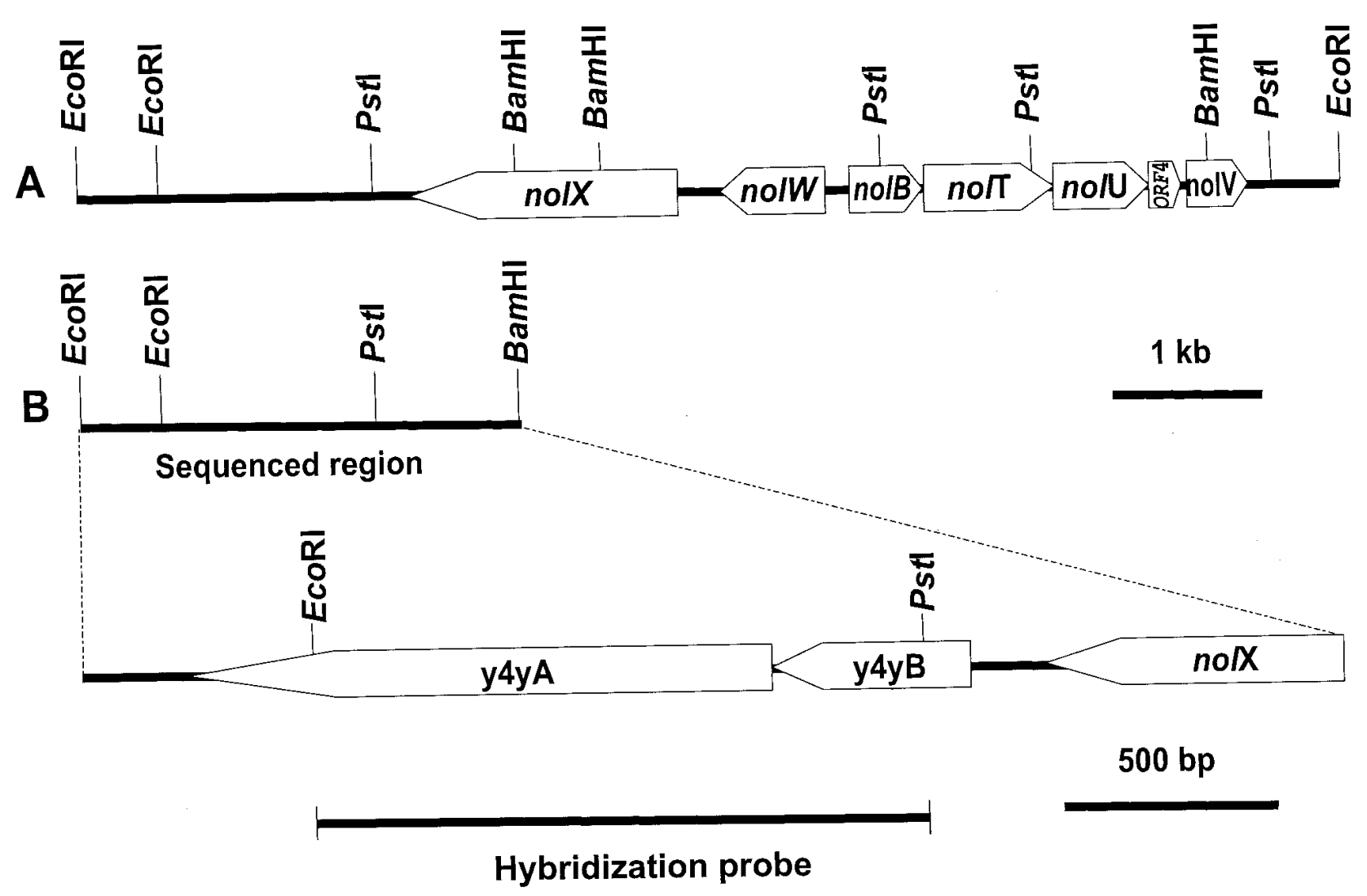

Fig. 1. A, Coordinated physical and genetic maps of cultivar-specificity region of Sinorhizobium fredii USDA257. B, DNA segment that was sequenced and orientation of open reading frames are shown. The 1.4-kb Pst I and EcoRI fragment used as a y4yA- and y4yB-specific probe is highlighted. 
the chromosome. To distinguish between the chromosomal and symbiotic plasmid copies of y4yA and y4yB of $S$. fredii USDA257, we have designated y4yAsp, y4yBsp to represent the symbiotic plasmid copies and $\mathrm{y} 4 \mathrm{yAc}, \mathrm{y} 4 \mathrm{yBc}$ to represent the chromosomal copies.

To isolate y4yAc and $\mathrm{y} 4 \mathrm{yBc}$, we screened a genomic library of $S$. fredii USDA257 with the 1.4-kb PstI-EcoRI fragment (Fig. 1) as a hybridization probe. Four cosmid clones were isolated and a $4.0-\mathrm{kb}$ EcoRI hybridizing fragment was subcloned in pGEM-7Zf(+) and pRK415 as pHBK39 and pHBK40, respectively. Subsequently, adjacent DNA fragments were also cloned and a total of 2,580 bp was sequenced. Analysis of the sequenced region revealed two ORFs that were very similar to $\mathrm{y} 4 \mathrm{yBsp}$ and $\mathrm{y} 4 \mathrm{yAsp}$. The $\mathrm{y} 4 \mathrm{yAc}$ and $\mathrm{y} 4 \mathrm{yBc}$ gene products encode proteins of 49,526 and 15,609 Da, respectively. The 600 -bp sequences upstream of y4yBc had no similarity to the sequences present in the plasmid copy, indicating that nolX was not reiterated in the chromosome. A comparison of the deduced amino acid sequence of $S$. fredii USDA257 Y4YAsp and Y4YBsp to that of Rhizobium sp. strain NGR234 homologues revealed greater than $90 \%$ identity (Fig. 3). S. fredii USDA257 Y4YAsp and Y4YAc share $85 \%$ amino acid identity, and Y4YBsp and Y4YBc exhibit 78\% identity (Fig. 3). Rhizobium sp. strain NGR234 y4yA and $S$. fredii USDA257 y4yAc encode a protein of 457 amino acids while $S$. fredii USDA257 y4yAsp encoded a protein of 450 amino acids (Fig. 3).

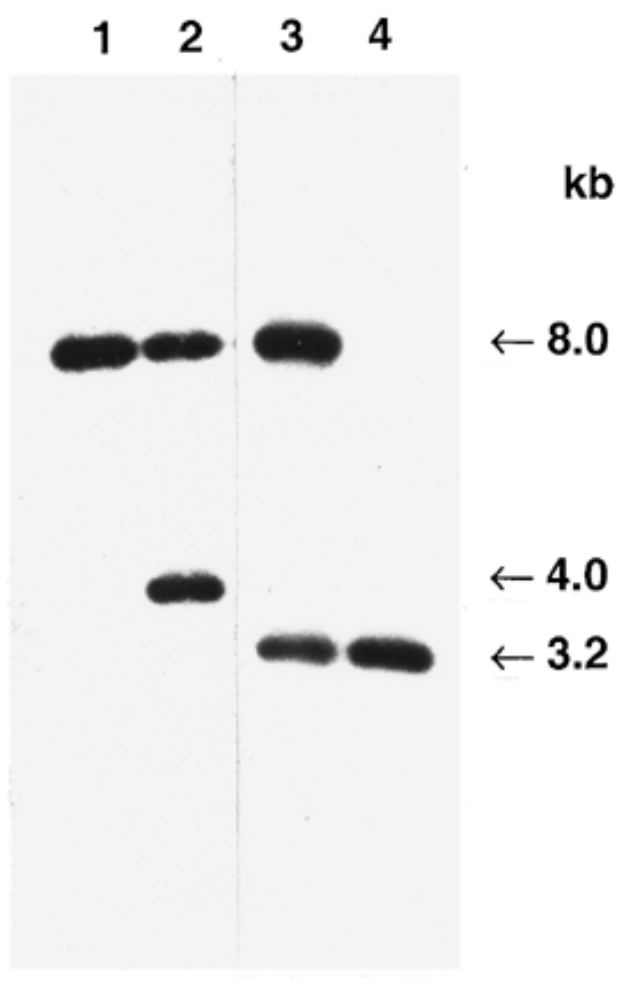

Fig. 2. Southern blot analysis of y4yA and y4yB in Sinorhizobium fredii and Rhizobium sp. strain NGR234. Genomic DNA from USDA191 (lane 1), USDA257 (lane 2), Rhizobium sp. strain NGR234 (lane 3), and its plasmid-cured derivative Rhizobium sp. strain ANU265 (lane 4) was digested with EcoRI and the blot probed with the 1.4-kb EcoRI/PstI fragment (see Figure 1). Arrows indicate sizes of hybridizing fragments.
Nucleotide sequence analysis revealed that nolX, y4yBsp, and y4yAsp are closely spaced and transcribed in the same direction, suggesting that these genes could be a part of an operon. To test this, we isolated RNA (Wang and Stacey 1991) from USDA191, USDA257, and USDA257 nolX mutant grown in the presence and absence of $1 \mu \mathrm{M}$ genistein. Ten micrograms of RNA was resolved on a $1.5 \%$ agarose gel containing formaldehyde, then transferred to a Nylon membrane by capillary blotting. After transfer, the membrane was baked at $80^{\circ} \mathrm{C}$ for $1 \mathrm{~h}$ and hybridized to a ${ }^{32} \mathrm{P}$-labeled, $1.4-\mathrm{kb}$ PstI/EcoRI fragment that contains most of y4yAsp and y4yBsp. Northern (RNA) blot analysis indicated that in both $S$. fredii USDA191 and USDA 257, y4yAsp and y4yBsp probe hybridized to a 2.5-kb RNA transcript only when the cells were grown in the presence of genistein (Fig. 4). However, inactivation of nolX resulted in no detectable RNA transcript. Our Northern blot analysis clearly shows that expression of y4yAsp and y4yBsp is dependent on nolX. Thus, nolX, y4yBsp, and y4yAsp appear to constitute an operon. Similar transcriptional organization of these genes is also found in Rhizobium sp. strain NGR234 and the expression of this gene cluster is induced within $1 \mathrm{~h}$ after induction with flavonoids (Perret et al. 1999).

Since $S$. fredii USDA191 contains only the plasmid copy and, unlike USDA257, lacks the chromosomal copy, we tested the role of the chromosomal copy in cultivar-specific nodulation of soybeans. We first introduced the pHBK40 into $S$. fredii USDA191 by triparental mating. S. fredii USDA191 transconjugants carrying both the plasmid and chromosomal copies nodulated both Peking and McCall soybean cultivars. To create mutants of y4yAsp and y4yBsp, a 2.4-kb EcoRIBamHI fragment from pRfDH412 was subcloned into the SmaI site of the suicide plasmid pJQ200uc1 (Quandt and Hynes 1993) to produce pJQ200uc1-24. A 1.3-kb PstI kanamycin cassette from pUC-4K (Vieira and Messing 1982) was inserted into the PstI site, inactivating the y4yBsp and y4yAsp genes and producing the plasmid pJQ200uc1-24km. The $\mathrm{y} 4 \mathrm{yBc}$ and $\mathrm{y} 4 \mathrm{yAc}$ genes were mutated as follows. A 6.3$\mathrm{kb}$ HindIII fragment was excised from pHBK366 and subcloned in the SmaI site of pJQ200uc1 to produce plasmid pJQ200uc1-63. Subsequently this plasmid was digested with PstI, resulting in the loss of 508-bp and 648-bp regions within $\mathrm{y} 4 \mathrm{yBc}$ and $\mathrm{y} 4 \mathrm{yAc}$, respectively. A 1-kb chloramphenicol cassette from pCAT19 was excised and cloned into the PstIdigested plasmid pJQ200uc1-63 and the resulting plasmid was named pJQ200uc1-63CAT. The mutant constructs were mobilized into $S$. fredii USDA257 by triparental mating with the helper plasmid pRK2013 (Figurski and Helinski 1979). Marker exchange was achieved by selection on YEM (yeast extract-mannitol) plates (Vincent 1970) containing 5\% (wt/vol) sucrose. Mutants were confirmed by Southern blot hybridization (Maniatis et al. 1982). Inactivation of either the plasmid or chromosomal copy, or the inactivation of both copies, had no effect on the inability of USDA257 to nodulate McCall. However, USDA257 y4yAsp and y4yBsp mutants retained their ability to form nitrogen-fixing nodules on Peking soybean.

We have earlier shown that inactivation of nolX abolishes the SR extracellular protein production by $S$. fredii USDA257 (Krishnan et al. 1995). To examine whether inactivation of y4yAsp and y4yBsp, whose expression is dependent on nolX, had any effect on SR extracellular protein production, we iso- 
lated the extracellular proteins from these mutants grown in the presence and absence of genistein, a potent inducer of nod genes of $S$. fredii (Krishnan and Pueppke 1991b). Induction and detection of SR extracellular proteins were performed as described earlier (Krishnan and Pueppke 1993). Inactivation of either the chromosomal or plasmid-borne copies of y4yA and $y 4 y B$ did not prevent these mutants from elaborating the SR extracellular proteins. A double mutant, in which both the chromosomal and plasmid copies of y4yA and y4yB were inactivated, also was not impaired in its ability to produce SR extracellular proteins (data not shown).

We tested the occurrence of y4yAsp and y4yBsp sequences in 23 different Rhizobium spp. obtained from the USDA collection by Southern blot analysis with a 1.4-kb PstI-EcoRI fragment (Fig. 1) as a hybridization probe. We observed strong hybridization to two EcoRI fragments in USDA257,
A

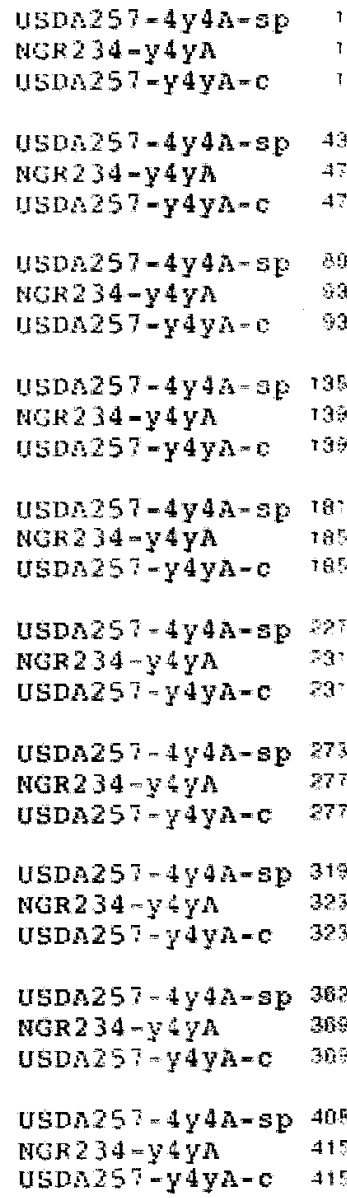

$4 \operatorname{spn} 257=y 4 y B-30$

$\operatorname{MUR} 234=\mathrm{Y}^{4} \mathrm{Y}^{\mathrm{B}}$

USDA25 $7-y 4 \mathrm{yE}-\mathrm{C}$

USDR257-Y4yB-9P $\operatorname{NOR} 234-y 4 y 0$ USDA257-y $4 \mathrm{YB}=0$

$\operatorname{USD} 257-y 4 \mathrm{~B}-3 \mathrm{p}$ MGR $234-y+y 0$ USDA $257-y 4 y B-c$

USDA257-Y4y $\mathrm{BP}$ NGR234-y $3 \mathrm{Y}$ USDA $257-Y 4 Y D-0$

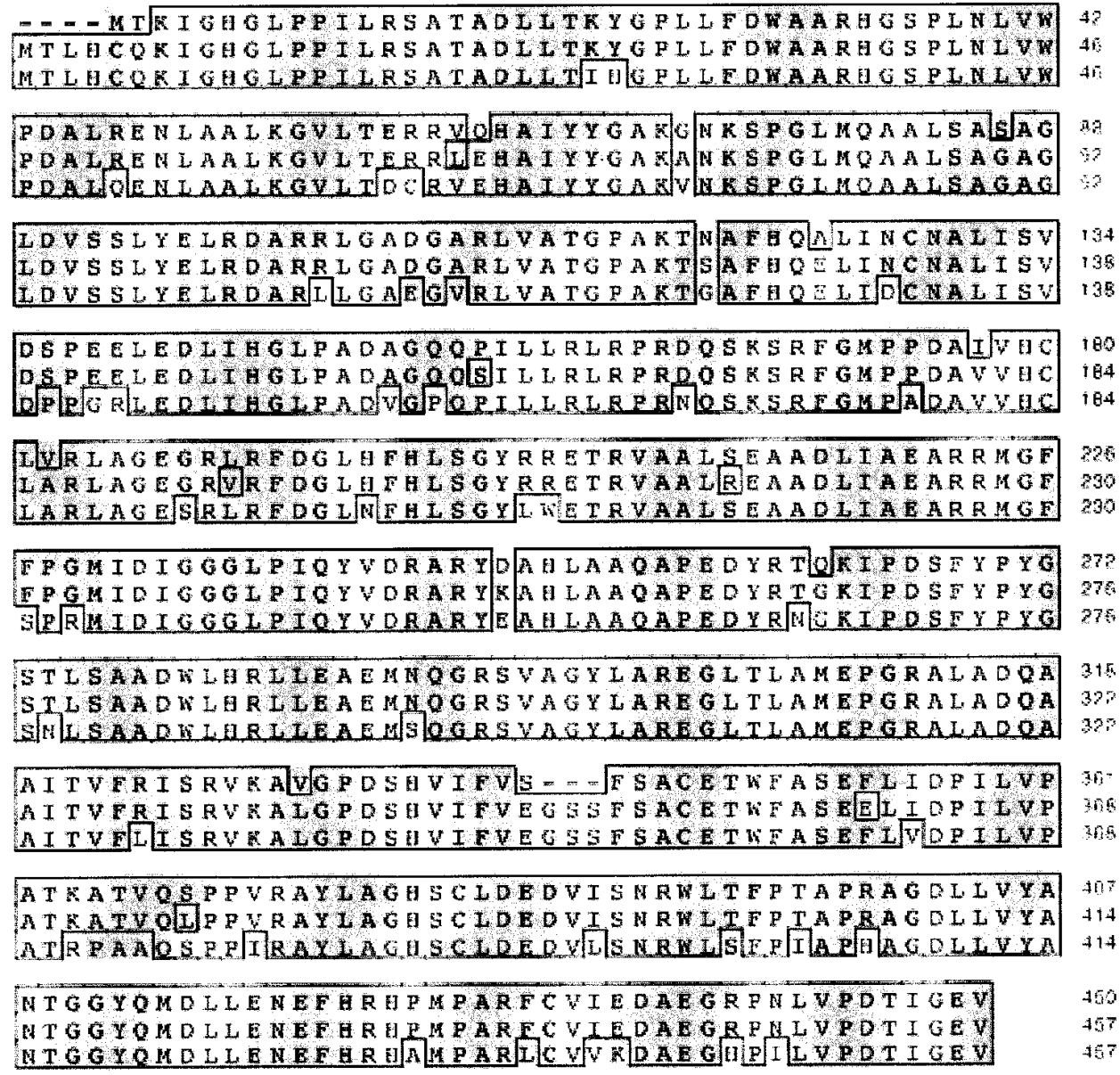

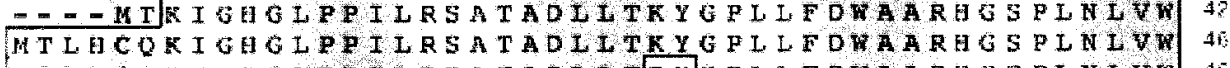

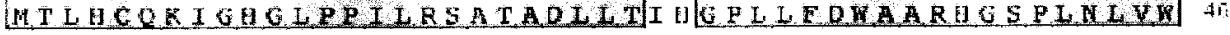

POALRENLAALKGVLTERRNOAAIYYGARGAKSPGLMOAALSASAG MA PDALRE MLALKGVLTERRLEHAI YYGAKANKBPGLMOAALSAGAG

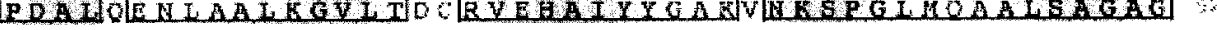

LDVSSLYELRDARRLGADGARLVATGFARTNAFEOALINCUALISV IGA LDVS S Y ELRDARRLGADGARLVA TGEARTSAFEOLINCNALISV 138

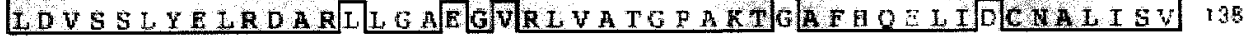

DEPEELEDLIHGLPADAGOORILIRLRPRDOSKSRFGHPPOAIVEO 180 DSPEELEDLIHGLPA DAGOOEILLRLRRROOS SRFGMPEDAVVHC TU4

DUVLAGEGRLRFDGL AFHLSGYRETRVAALSERADLTAEARRMGF 226 LARLASEGRURF DGLUFHLSGYRRETRVAALEEAALIAEARRMGE Z9O LARLAGESRLRFDGLWEHLSGYL WETAVAALSEAADLTAEARRMGE 290

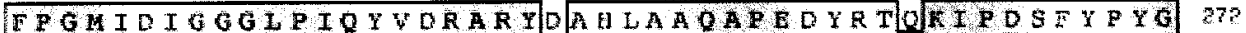

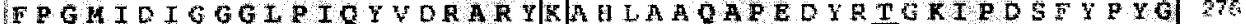

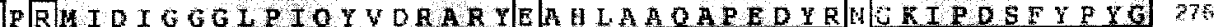

STLSAADKLGRILEAEMHOGRSWAGYLAREOLTLAMEPGRALADQA 315 STLSAADWLGRLLEAEMNOGRSYAGYLARGLTIAMEPGRALADOA 32\%

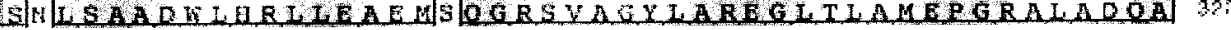

AITVERISRVEAUG POEVIFVB- - - FACETWFASETIDFILVP AI TVRRISRVRALGPDSGVIFUEG S F ACETWFAEELIOPILVP 305

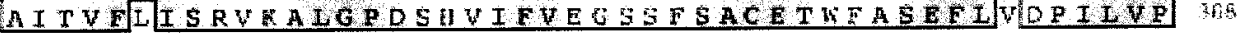

ATKATVOSPPVRAYLAGESCLDEDVISWRULTFPTAPRAGDLLVYA AT ATATVOLIP PURAYLAG GCLDEDVISNRWLIFPTAPRAGDLLVIA 414

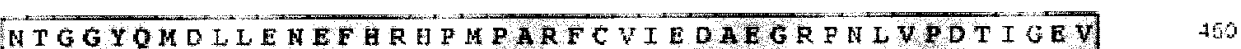
MTGMOMDLLENEEHRERUPARLCVYRDAEGIILVPDTIGEV

Fig. 3. Amino acid comparison of (A) Y4YA and (B) Y4YB between Sinorhizobium fredii USDA257, Rhizobium sp. strain NGR234 (Y4YA, accession no. P55709; Y4YB, accession no. P55710). Alignment was created with the PILEUP program (Genetics Computer Group, Madison, WI). Identical amino acids are boxed. 


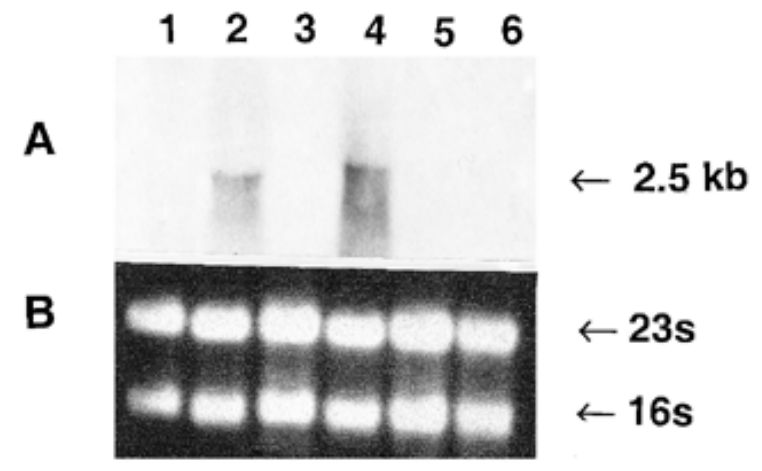

Fig. 4. Northern (RNA) blot analysis of flavonoid induction of y4yA and $\mathrm{y} 4 \mathrm{yB}$ of Sinorhizobium fredii. RNA was isolated from bacteria grown in the absence (lanes 1, 3,5) or presence (lanes $2,4,6)$ of $1 \mu \mathrm{M}$ genistein. Ten micrograms of RNA was resolved on a formaldehyde agarose gel and transferred to a Nylon membrane. A, Blots were hybridized with a 1.4-kb PstI/EcoRI fragment that contains most of y4yA and y4yB. B, Ethidium-bromide-stained gel picture showing uniform loading and integrity of RNA samples. RNA sources: lanes 1 and 2, USDA191; lanes 3 and 4, USDA257; lanes 5 and 6, USDA257 nolX mutant.

Rhizobium sp. strain NGR234, and S. saheli USDA4893. Weakly hybridizing, single EcoRI fragments were also detected in Mesorhizobium tianshanense USDA3592, M. amorphae USDA10001, $R$. tropici USDA9030, $R$. mongolense USDA1844, $R$. etli USDA9032, $R$. galegae USDA4128, and $R$. hainanense USDA3588. No homologous sequences to USDA257 y4yAsp and y4yBsp were detected in Azorhizobium caulinodans USDA4892, Bradyrhizobium japonicum USDA6, B. liaoningense USDA3622, B. elkanii USDA76, $R$. huautlaense USDA4900, $R$. leguminosarum USDA2370, Mesorhizobium ciceri USDA3383, M. huakuii USDA4779, M. loti USDA3471, M. mediterraneum USDA 3392, and $S$. medicae USDA 1037. The occurrence of nolX, y4yBsp, and y4yAsp sequences in Rhizobium sp. strain NGR234, and their absence in Bradyrhizobium spp., indicates that these genes may be involved in cellular processes other than soybean cultivar specificity. In fact, USDA257 y4yBsp and y4yBc are significantly similar to diaminopimelate decarboxylase, the last enzyme of the lysine biosynthetic pathway in bacteria.

\section{ACKNOWLEDGMENTS}

This work was supported by a competitive research grant from the United States Department of Agriculture/National Research Initiative to H. B. K. We would like to thank Steve Pueppke for his interest during the initial part of this work, and Jan Miernyk, Larry Darrah, and Jerry White for critical reading of the manuscript.

\section{LITERATURE CITED}

Bellato, C. M., Balatti, P. A., Pueppke, S. G., and Krishnan, H. B. 1996. Proteins from cells of Rhizobium fredii bind to DNA sequences preceding nolX, a flavonoid-inducible nod gene that is not associated with a nod box. Mol. Plant-Microbe Interact. 9:457-463.

Bellato, C. M., Krishnan, H. B., Cubo, T., Temprano, F., and Pueppke, S. G. 1997. The soybean cultivar specificity gene nolX is present, expressed in a nodD-dependent manner, and of symbiotic significance in cultivar-nonspecific strains of Rhizobium (Sinorhizobium) fredii. Microbiology 143:1381-1388.

Figurski, D., and Helinski, D. R. 1979. Replication of an origincontaining derivative of plasmid $\mathrm{RK}_{2}$ dependent on a plasmid function provided in trans. Proc. Natl. Acad. Sci. USA 76:1648-1652.
Freiberg, C., Fellay, R., Bairoch, A., Broughton, W. J., Rosenthal, A., and Perret, X. 1997. Molecular basis of symbiosis between Rhizobium and legumes. Nature 387:394-401.

Gu, J., Balatti, P. A., Krishnan, H. B., and Pueppke, S. G. 1997. Characterization of the overlapping promoters of nolB and nolW, two soybean cultivar specificity genes from Rhizobium fredii strain USDA257. Mol. Plant-Microbe Interact. 10:138-141.

Heron, D. S., Ersek, T., Krishnan, H. B., and Pueppke, S. G. 1989. Nodulation mutants of Rhizobium fredii USDA257. Mol. PlantMicrobe Interact. 2:4-10.

Heron, D. S., and Pueppke, S. G. 1984. Mode of infection, nodulation specificity, and indigenous plasmids of 11 fast growing Rhizobium japonicum strains. J. Bacteriol. 160:1061-1066.

Keyser, H. H., Bohlool, B. B., Hu, T. S., and Weber, D. F. 1982. Fastgrowing rhizobia isolated from root nodules of soybean. Science 215 : 1631-1632.

Kovács, L. G., Balatti, P. A., Krishnan, H. B., and Pueppke, S. G. 1995. Transcriptional organization and expression of nolXWBTUV, a locus that regulates cultivar-specific nodulation of soybean by Rhizobium fredii USDA257. Mol. Microbiol. 17:923-933.

Krishnan, H. B., Kuo, C.-L., and Pueppke, S. G. 1995. Elaboration of flavonoid-induced proteins by the nitrogen-fixing soybean symbiont Rhizobium fredii is regulated by both nodD1 and nodD2, and is dependent on the cultivar-specificity locus, nolXWBTUV. Microbiology 141:2245-2251.

Krishnan, H. B., and Pueppke, S. G. 1991a. nolC, a Rhizobium fredii gene involved in cultivar-specific nodulation of soybeans, shares homology with a heat-shock gene. Mol. Microbiol. 5:737-745.

Krishnan, H. B., and Pueppke, S. G. 1991b. Sequence and analysis of the nodABC region of Rhizobium fredii USDA257, a nitrogen-fixing symbiont of soybean and other legumes. Mol. Plant-Microbe Interact. 4:512-520.

Krishnan, H. B., and Pueppke, S. G. 1992. Inactivation of nolC conditions developmental abnormalities in nodulation of Peking soybean by Rhizobium fredii USDA257. Mol. Plant-Microbe Interact. 5:14-21.

Krishnan, H. B., and Pueppke, S. G. 1993. Flavonoid inducers of nodulation genes stimulate Rhizobium fredii USDA257 to export proteins into the environment. Mol. Plant-Microbe Interact. 6:107-113.

Maniatis, T., Fritsch, E. F., and Sambrook, J. 1982. Molecular Cloning: A Laboratory Manual. Cold Spring Harbor Laboratory, Cold Spring Harbor, NY.

Meinhardt, L. W., Krishnan, H. B., Balatti, P. A., and Pueppke, S. G. 1993. Molecular cloning and characterization of a sym plasmid locus that regulates cultivar-specific nodulation of soybean by Rhizobium fredii USDA257. Mol. Microbiol. 9:17-29.

Perret, X., Fellay, R., Bjourson, A. J., Cooper, J. E., Brenner, S., and Broughton, W. J. 1994. Subtraction hybridization and shot-gun sequencing: A new approach to identify symbiotic loci. Nucleic Acids Res. 22:1335-1341.

Perret, X., Freiberg, C., Rosenthal, A., Broughton, W. J., and Fellay, R. 1999. High-resolution transcriptional analysis of the symbiotic plasmid of Rhizobium sp. strain NGR234. Mol. Microbiol. 32:415-425.

Pueppke, S. G., and Broughton, W. J. 1999. Rhizobium sp. strain NGR234 and $R$. fredii USDA257 share exceptionally broad, nested host ranges. Mol. Plant-Microbe Interact. 12:293-318.

Pueppke, S. G., DeBoer, M., He, X.-T., and Krishnan, H. B. 1999. An isoflavone from soybean roots induces Sinorhizobium fredii strain USDA257 to produce pilus-like surface appendages. Pages 131-134 in: Highlights of Nitrogen Fixation Research. E. Martinez and G. Hernandez, eds. Kluwer Academic/Plenum Publishers, New York.

Quandt, U., and Hynes, M. F. 1993. Versatile suicide vectors which allow direct selection for gene replacement in Gram-negative bacteria. Gene 127:15-21.

Vieira, J., and Messing, J. 1982. The pUC plasmids, and M13mp7derived system for insertion mutagenesis and sequencing with synthetic universal primers. Gene 19:259-268.

Vincent, J. M. 1970. A Manual for the Practical Study of Root-Nodule Bacteria. Blackwell Science, Oxford.

Viprey, V., Del Greco, A., Golinowski, W., Broughton, W. J., and Perret, X. 1998. Symbiotic implications of type III protein secretion machinery in Rhizobium. Mol. Microbiol. 28:1381-1389.

Wang, S., and Stacey, G. 1991. Studies of the Bradyrhizobium japonicum nodD1 promoter: A repeated structure for the nod box. J. Bacteriol. 173:3356-3365. 